\title{
Effect of Human Urine and Cattle Urine on Growth and Yield of Tomato (Solanum lycopersicum) in Red, Laterite and Black Soils of Karnataka, India
}

\author{
H. Yogeeshappa ${ }^{1^{*}}$ and C.A. Srinivasamurthy ${ }^{2}$ \\ ${ }^{1}$ Department of Soil Science and Agricultural Chemistry, College of Horticulture, \\ Munirabad (Koppal) - 583 233, UHS Bagalkot, Karnataka, India \\ ${ }^{2}$ Department of Soil Science and Agricultural Chemistry, College of Agriculture, \\ Gandhi Krishi Vigyan Kendra, Bangalore-560065, Karnataka, India \\ *Corresponding author
}

\begin{tabular}{|c|c|}
\hline \multicolumn{2}{|r|}{ A B S T R A C T } \\
\hline & \multirow{6}{*}{$\begin{array}{l}\text { The experiment was conducted under green house in the Department of Soil Science and } \\
\text { Agricultural Chemistry, University of Agriculture, G.K.V.K., Bangalore, to evaluate the } \\
\text { levels of nitrogen as well as human urine and cattle urine as nutrients sources on tomato } \\
\text { crop (Solanum lycopersicum). The treatments consisted the recommended dose of NPK } \\
\text { through fertilizers (control), } 1.5 \text { and } 2 \text { times the recommended dose of } \mathrm{N} \text { through fertilizers } \\
\text { plus recommended dose of } \mathrm{P} \text { and } \mathrm{K} \text {, recommended dose of } \mathrm{N}, 1.5 \text { and } 2 \text { times the } \\
\text { recommended dose of } \mathrm{N} \text { through human urine as well as cattle urine and balanced P and } \mathrm{K} \\
\text { through fertilizers. Significantly higher plant height }(87.2 \text { and } 80.2 \mathrm{~cm} \text {, respectively), } \\
\text { number of branches ( } 5.90 \text { and } 5.80 \text {, respectively), and number of leaves ( } 40.8 \text { and } 36.2) \text { at } \\
\text { harvest were recorded with } 2 \text { times the recommended dose of } \mathrm{N} \text { (Nitrogen) through human } \\
\text { urine to tomato crop as soil application for red and laterite soil, respectively. Whereas, in } \\
\text { black soil, higher plant height }(93.9 \mathrm{~cm}) \text {, number of branches }(6.90) \text {, number of leaves } \\
\text { (41.5) and total dry matter accumulation }\left(249.8 \mathrm{~g} \text { plant } \mathrm{t}^{-1}\right) \text { were recorded with } 2 \text { times the } \\
\text { recommended dose of } \mathrm{N} \text { application through chemical fertilizer. Application of } 2 \text { times the } \\
\text { recommended dose of } \mathrm{N} \text { through human urine in red and laterite soil recorded the } \\
\text { significantly higher fruit yield }\left(3.6 \text { and } 3.4 \mathrm{~kg}_{\text {plant }}{ }^{-1} \text {, respectively) at harvest. }\right.\end{array}$} \\
\hline Keywords & \\
\hline & \\
\hline Artic & \\
\hline & \\
\hline & \\
\hline
\end{tabular}

\section{Introduction}

Modern agriculture gets the nitrogen it needs from ammonia- producing plants that utilize fossil fuels such as natural gas, LPG or petroleum naphtha as a source of hydrogen. This energy- intensive process dumps carbon dioxide into the atmosphere and consumes a finite hydrocarbon resource. Modern agriculture gets the phosphorous it needs from phosphorous- bearing rocks. But these reserves are rapidly dwindling and increasingly contaminated with pollutants such as cadmium. On a yearly basis a human produces roughly 500 liters of urine and 50 liters of feces, and these two products contain enough nutrients to grow most of the plants that this person needs as food.

But instead of utilizing these 550 liters as a valuable resource, we mix it with roughly 15,000 liters of water and all goes down the drain. Before it reaches the sewage plant, if there is one, this slurry gets mixed with 
hundreds of pollutants along the way. The conventional sewage plant rarely retains or destroys all bacterial and viral contaminants, it produces a large amount of sludge generally unfit for agriculture, and it causes severe pollution in freshwater and seawater ecosystems.

This end of pipe solution recycles nothing. It takes valuable resources and transforms them into pollutants. As fertilizer prices rise throughout the world, and as water becomes an increasingly scarce commodity, this approach is not sustainable and makes no sense.

The nutrients in urine are in the forms which are readily available to plants. The nitrogen is in the form of urea which readily degrades to ammonium and nitrate forms and phosphorous, potassium and sulphates are in ionic forms. This makes urine a unique biogenic fertiliser.

Soil-plant-environment system should be free from economic exploitation and overuse and misuse of the inputs. No doubt, the use of mineral fertilizers and pesticides was a boon in the past, but their non-judicious use is being considered a bane in the present scenario, causing for a shift towards organic farming which has its own limitations. It is now time to reanalyse the production advantage to the cost of nature destruction, where impairment of soil physical, chemical and biological properties are the key problems associated with indiscriminate and over use of synthetic fertilizers and pesticides.

The judicious use of naturally available resources like human urine (anthropogenic liquid waste) and cattle urine help in maintaining yield stability through correction of marginal deficiencies of macro and micronutrients, enhancing efficiency of applied nutrients and providing favorable soil chemical and physical conditions and reducing the environmental pollution.

Therefore judicious use of anthropogenic liquid waste in the areas of agriculture will increase, it might be insured that the quality and fertility of soils are not negatively affected in the long term perspective. This means in the practice that there is a need for research on efficiency and impact of these nutrient sources on different types of soils.

Taking all these factors into consideration, under greenhouse condition a pot-culture experiment was conducted to evaluate the effect of application of human and cattle urine on growth and yield of tomato in red, laterite and black soils.

\section{Materials and Methods}

A pot culture experiment was conducted under greenhouse condition in the Department of Soil Science and Agricultural Chemistry, at College of Agriculture, GKVK, UAS, Bangalore.

The red soil was collected from the field at Dblock, ZARS, UAS, GKVK, Bangalore. The laterite soil was collected from the Seed Farm Unit, ZARS, UAS, Bramhavara (coastal area), and the black soil was collected from farmer's field near Nanjanagud, Mysore district.

The soil samples were analyzed for physical and chemical properties and found initial physico-chemical properties of red, laterite and black soils are given in Table 1. Fifteen kilogram of soil was weighed on to a polyethylene sheet and calculated quantity of fertilizers was added as per the treatment and same was transferred to the pots. Then one month old tomato seedlings were transplanted and watering was done to reduce the transplanting shock on seeding and for better establishment of the crop. 
Simultaneously human urine was collected from Kannada medium High school, Doddaballapura by using specialized structure which separates fecal matter and urine and the cattle urine was collected from farmers cattle shed in Doddaballapura area at early hours of the day. Stored the urine for one month before soil application, meanwhile before soil application draw the sample both human and cattle urine and subjected for elemental analysis. Based on the chemical characteristics of the urine calculate the quantity of urine required for soil application as nutrient sources. The chemical composition for human urine was $0.30,0.17,0.18$ per cent, $\mathrm{N}, \mathrm{P}_{2} \mathrm{O}_{5}$ and $\mathrm{K}_{2} \mathrm{O}$, respectively and cattle urine had $0.25,0.12$ and 0.16 per cent $\mathrm{N}, \mathrm{P}_{2} \mathrm{O}_{5}$ and $\mathrm{K}_{2} \mathrm{O}$, respectively.

The quantity of human and cattle urine was calculated based on the nitrogen content of urine and dosage of nitrogen recommended for the crop was 250: $250: 250 \mathrm{~kg}$ of NPK $\mathrm{ha}^{-1}$. Total volume of urine, quantity of fertilizers and the quantity of nutrients $(\mathrm{kg}$ $\mathrm{ha}^{-1}$ ) added through human urine, cattle urine and fertilizer to tomato crop as per the treatments was used has been presented in Table 2.

The total volume of human urine/ cattle urine required per hectare to meet the recommended dose of nitrogen $(\mathrm{kg} / \mathrm{ha})$ was calculated by using bellow mentioned formula.

Volume of human/ cattle urine $(\mathrm{m} 3$ ha 1$)=$ (Recommended dose of nitrogen $\times 100) /(\mathrm{Per}$ cent total nitrogen in human/ cattle urine $x$ 1000)

The calculated quantity of gypsum was applied as basal dose only in case of treatments receiving the human urine and cattle urine with gypsum as per the treatment details to overcome the effect of sodium if any on soil physical and chemical properties. The quantity of gypsum applied was $6.45 \mathrm{~kg}$ per cubic meter of urine, which was arrived at by considering the per cent sodium percent in urine (an average of 0.3 per cent $\mathrm{Na}$ ).

The treatments consisted the recommended dose of NPK through fertilizers (control), 1.5 and 2 times the recommended dose of $\mathrm{N}$ through fertilizers plus recommended dose of $\mathrm{P}$ and $\mathrm{K}$, recommended dose of $\mathrm{N}, 1.5$ and 2 times the recommended dose of $\mathrm{N}$ through human urine as well as cattle urine and balanced $\mathrm{P}$ and $\mathrm{K}$ through fertilizers. The design of the experiment was carried out by using completely randomized design (CRD) with three replications.

Recorded the data on plant growth attributes viz., plant height, number of branches plant ${ }^{-1}$, number of leaves plant ${ }^{-1}$ and total dry matter (g/plant) of tomato at harvest. Recorded the observations on number of fruit per plant at 60, 90 days after transplanting and at final harvest, fresh weight $\left(\mathrm{g}\right.$ fruit $\left.^{-1}\right)$ and the fruit yield $\left(\mathrm{kg} \mathrm{plant}^{-1}\right)$. The experimental data were analysed statistically.

\section{Results and Discussion}

\section{Growth attributes}

\section{Plant height (cm)}

Significantly higher plant height was recorded in red soil with application of 2 times the recommended dose of nitrogen through human urine $\left(\mathrm{T}_{6}\right)$ at harvest $(87.2 \mathrm{~cm})$ which was on par with 2 times the recommended dose of nitrogen through cattle urine $\left(T_{9}\right), 2$ times the recommended dose of nitrogen through chemical fertilizers $\left(\mathrm{T}_{3}\right)$ and 1.5 times recommended dose of nitrogen through human urine $\left(\mathrm{T}_{5}\right)$, cattle urine $\left(\mathrm{T}_{8}\right)$ and fertilizers $\left(\mathrm{T}_{2}\right)$. The treatment receiving recommended dose of nitrogen through 
chemical fertilizers $\left(\mathrm{T}_{1}\right)$ recorded significantly lower plant height of $78.1 \mathrm{~cm}$ and it was on par with recommended dose of nitrogen through human urine $\left(\mathrm{T}_{4}\right)$ and cattle urine $\left(T_{7}\right)$. Similar trend was observed at harvest of tomato crop in laterite soil also. In black soil, significantly higher plant height $(93.9 \mathrm{~cm})$ at harvest of tomato crop was recorded with application of 2 times the recommended dose of nitrogen through chemical fertilizers $\left(\mathrm{T}_{3}\right)$ and it was on par with 2 times the recommended dose of nitrogen through human urine $\left(\mathrm{T}_{6}\right)$ and cattle urine $\left(\mathrm{T}_{9}\right)$ and 1.5 times recommended dose of nitrogen through fertilizers $\left(\mathrm{T}_{2}\right)$, human urine $\left(\mathrm{T}_{5}\right)$ and cattle urine $\left(\mathrm{T}_{8}\right)$.

Significantly lower plant height $(85.7 \mathrm{~cm})$ was recorded with recommended dose of nitrogen through cattle urine $\left(\mathrm{T}_{7}\right)$ and it was on par with recommended dose of nitrogen through human urine $\left(\mathrm{T}_{4}\right)$ and chemical fertilizer $\left(T_{1}\right)$ treatments (Table 3$)$. The similar trend of results was observed by Jonsson (1997), Sridevi et al., (2009) and Guadarrama et al., (2001).

\section{Number of branches (plant ${ }^{-1}$ )}

Significantly maximum number of branches plant $^{-1}\left(5.90\right.$ plant $\left.^{-1}\right)$ at harvest of tomato crop in red soil was recorded in treatment receiving 2 times the recommended dose of nitrogen through human urine $\left(\mathrm{T}_{6}\right)$ which was on par with $\mathrm{T}_{9}, \mathrm{~T}_{3}, \mathrm{~T}_{5} \mathrm{~T}_{8}$ and $\mathrm{T}_{2}$. Recommended dose of nitrogen through chemical fertilizer to crop $\left(\mathrm{T}_{1}\right)$ recorded significantly lower number of branches plant ${ }^{-1}$ (5.15) and it was at par with $\mathrm{T}_{4}$ and $\mathrm{T}_{7}$.

The same trend was observed at harvest of tomato crop in laterite soil also. In case of black soil, significantly maximum number of branches plant ${ }^{-1}\left(6.90\right.$ plant $\left.^{-1}\right)$ at harvest of crop was recorded in treatment receiving 2 times the recommended dose of nitrogen through chemical fertilizer $\left(\mathrm{T}_{3}\right)$ which was on par with $\mathrm{T}_{6}, \mathrm{~T}_{9}, \mathrm{~T}_{2}, \mathrm{~T}_{5}$ and $\mathrm{T}_{8}$. Treatment receiving recommended dose of nitrogen through cattle urine to crop $\left(\mathrm{T}_{7}\right)$ recorded significantly lower number of branches plant ${ }^{-1}$ (5.13) and it was at par with $\mathrm{T}_{4}$ and $\mathrm{T}_{1}$ (Table $3)$. These results are in agreement with the findings of Peter Morgan (2004) and Kedar Man Prajapati, Deepak Raj Gajurel (2003) who used source separated human urine as the nutrient source for the vegetable plants particularly broadbean, blackgram and green pea.

\section{Number of leaves (plant $\left.{ }^{-1}\right)$}

In red soil, significantly maximum number of leaves plant ${ }^{-1}(40.8)$ at harvest in red soil was recorded with application of 2 times the recommended dose of nitrogen through human urine $\left(\mathrm{T}_{6}\right)$ which was on par with $\mathrm{T}_{9}$, $\mathrm{T}_{3}, \mathrm{~T}_{5} \mathrm{~T}_{8}$ and $\mathrm{T}_{2}$. Application of recommended dose of nitrogen through chemical fertilizer $\left(\mathrm{T}_{1}\right)$ recorded significantly lower number of leaves plant $^{-1}$ (29.6) and it was at par with $\mathrm{T}_{4}$ and $\mathrm{T}_{7}$. Similar trend was observed at harvest of tomato crop in laterite soil. In case of black soil, significantly higher number of leaves plant $^{-1}$ (41.5) was noticed at harvest with the application of 2 times the recommended dose of nitrogen through chemical fertilizer $\left(\mathrm{T}_{3}\right)$ and it was on par with $\mathrm{T}_{6}, \mathrm{~T}_{9}, \mathrm{~T}_{2}, \mathrm{~T}_{5}$ and $\mathrm{T}_{8}$. Application of recommended dose of nitrogen through cattle urine $\left(\mathrm{T}_{7}\right)$ recorded significantly lower number of leaves plant ${ }^{-1}$ (29.5) and it was at par with $\mathrm{T}_{4}$ and $\mathrm{T}_{1}$ (Table $3)$. These results are in agreement with the findings of Peter Morgan (2004) and Kedar and Deepak (2003) used the source-separated human urine for the vegetable plants particularly broad bean, black gram and green pea and studied actual nutrient uptake by vegetable plants from source separated human urine and chemical fertilizers in soil media with different dilution or loading rate in the same condition can be investigated in terms of bio-mass growth. 


\section{The treatment details are as follows}

$\mathbf{T}_{1} \quad$ : Control-Recommended dose of NPK

$\mathbf{T}_{2}: 1.5$ times the recommended dose of $\mathrm{N}$ through fertilizer + Recommended dose of $\mathrm{P}$ and $\mathrm{K}$

$\mathbf{T}_{3} \quad: \quad 2$ times the recommended dose of $\mathrm{N}$ through fertilizer + Recommended dose of $\mathrm{P}$ and $\mathrm{K}$

$\mathbf{T}_{4} \quad: \quad$ Recommended dose of $\mathrm{N}$ through Human urine + Balance $\mathrm{P} \& \mathrm{~K}$ through fertilizer

$\mathbf{T}_{5}: 1.5$ times the recommended dose of $\mathrm{N}$ through Human urine + Balance $\mathrm{P} \& \mathrm{~K}$ through fertilizer

$\mathbf{T}_{6}: 2$ times the recommended dose of $\mathrm{N}$ through Human urine + Balance $\mathrm{P} \& \mathrm{~K}$ through fertilizer

$\mathbf{T}_{7} \quad:$ Recommended dose of $\mathrm{N}$ through Cattle urine + Balance $\mathrm{P} \& \mathrm{~K}$ through fertilizer

$\mathbf{T}_{\mathbf{8}} \quad: \quad 1.5$ times the recommended dose of $\mathrm{N}$ through Cattle urine + Balance $\mathrm{P} \& \mathrm{~K}$ through fertilizer

$\mathbf{T}_{9} \quad: \quad 2$ times the recommended dose of $\mathrm{N}$ through Cattle urine + Balance $\mathrm{P} \& \mathrm{~K}$ through fertilizer

Where: N-Nitrogen; P-Phosphorus; K-Potassium.

Note: Balance of $\mathrm{P}$ and $\mathrm{K}$ were supplied through single superphosphate (SSP) and Muriate of potash (MOP), respectively.

Table.1 Physico- chemical properties of the red, laterite and black soils

\begin{tabular}{|c|c|c|c|}
\hline Parameters & Red soil & Laterite soil & Black soil \\
\hline \multicolumn{4}{|c|}{ I. Physical properties } \\
\hline Textural class & Sandy Loam & Gravelly sandy loam & Clay \\
\hline \multicolumn{4}{|c|}{ II. Chemical properties } \\
\hline pH (1:2.5) & 6.19 & 4.97 & 8.43 \\
\hline$E C\left(d S ~ m^{-1}\right)$ & 0.18 & 0.09 & 0.29 \\
\hline Organic Carbon (\%) & 0.39 & 0.63 & 0.57 \\
\hline Available N $\left(\mathrm{kg} \mathrm{ha}^{-1}\right)$ & 225.15 & 210.09 & 378.4 \\
\hline Available $\mathrm{P}_{2} \mathrm{O}_{5}\left(\mathrm{~kg} \mathrm{ha}^{-1}\right)$ & 21.01 & 12.03 & 18.63 \\
\hline Available $\mathrm{K}_{2} \mathrm{O}\left(\mathrm{kg} \mathrm{ha}^{-1}\right)$ & 318.54 & 115.93 & 515.30 \\
\hline
\end{tabular}


Table. 2 Total volume and quantity of nutrients $\left(\mathrm{kg} \mathrm{ha}^{-1}\right)$ added through human urine, cattle urine and fertilizer to tomato crop as per the treatments

\begin{tabular}{|c|c|c|c|c|c|c|c|c|c|c|c|c|}
\hline \multirow{2}{*}{$\begin{array}{c}\text { Treatme } \\
\text { nts }\end{array}$} & \multirow{2}{*}{$\begin{array}{c}\text { HU/CU } \\
\left(\mathbf{m}^{3} \mathbf{h a}^{-1}\right)\end{array}$} & \multicolumn{3}{|c|}{ Fertiliser } & \multicolumn{3}{|c|}{ Human urine } & \multicolumn{3}{|c|}{ Cattle urine } & \multicolumn{2}{|c|}{$\begin{array}{l}\text { Balance } P \text { and } K \\
\text { through fertilizer }\end{array}$} \\
\hline & & $\mathbf{N}$ & $\mathbf{P}_{2} \mathbf{O}_{5}$ & $\mathrm{~K}_{2} \mathrm{O}$ & $\mathbf{N}$ & $\mathbf{P}_{2} \mathbf{O}_{5}$ & $\mathrm{~K}_{2} \mathrm{O}$ & $\mathbf{N}$ & $\mathbf{P}_{2} \mathbf{O}_{5}$ & $\mathrm{~K}_{2} \mathrm{O}$ & $\mathbf{P}_{2} \mathrm{O}_{5}$ & $\mathrm{~K}_{2} \mathrm{O}$ \\
\hline $\mathbf{T}_{1}$ & - & 250 & 250 & 250 & & & & & & & - & - \\
\hline $\mathbf{T}_{2}$ & - & 375 & 375 & 357 & & & & & & & - & - \\
\hline $\mathbf{T}_{3}$ & - & 500 & 500 & 500 & & & & & & & - & - \\
\hline $\mathbf{T}_{4}$ & 83.3 & & & & 250.0 & 141.7 & 150.0 & & & & 108.3 & 100.0 \\
\hline $\mathbf{T}_{5}$ & 125.0 & & & & 375.0 & 212.5 & 225.0 & & & & 162.5 & 150.0 \\
\hline $\mathbf{T}_{6}$ & 166.6 & & & & 500.0 & 283.3 & 300.0 & & & & 216.7 & 200.0 \\
\hline $\mathbf{T}_{7}$ & 100.0 & & & & & & & 250.0 & 120.0 & 160.0 & 130.0 & 90.0 \\
\hline $\mathbf{T}_{8}$ & 150.0 & & & & & & & 375.0 & 180.0 & 240.0 & 195.0 & 135.0 \\
\hline $\mathbf{T}_{9}$ & 200.0 & & & & & & & 500.0 & 240.0 & 320.0 & 260.0 & 180.0 \\
\hline
\end{tabular}

Table.3 Plant height $(\mathrm{cm})$, number of branches, number of leaves and total dry matter $(\mathrm{g} / \mathrm{plant})$ of tomato at harvest as influenced by graded levels of human urine, cattle urine and fertilizer in three different soils

\begin{tabular}{|c|c|c|c|c|c|c|c|c|c|c|c|c|}
\hline \multirow[b]{2}{*}{ Treatments } & \multicolumn{4}{|c|}{ Red soil } & \multicolumn{4}{|c|}{ Laterite soil } & \multicolumn{4}{|c|}{ Black soil } \\
\hline & $\begin{array}{c}\text { Plant } \\
\text { height }\end{array}$ & $\begin{array}{c}\text { No. of } \\
\text { branches }\end{array}$ & $\begin{array}{l}\text { No. of } \\
\text { leaves }\end{array}$ & $\begin{array}{c}\text { Total } \\
\text { dry } \\
\text { matter }\end{array}$ & $\begin{array}{c}\text { Plant } \\
\text { height }\end{array}$ & $\begin{array}{c}\text { No. of } \\
\text { branches }\end{array}$ & $\begin{array}{l}\text { No. of } \\
\text { leaves }\end{array}$ & $\begin{array}{c}\text { Total } \\
\text { dry } \\
\text { matter }\end{array}$ & $\begin{array}{c}\text { Plant } \\
\text { height }\end{array}$ & $\begin{array}{c}\text { No. of } \\
\text { branches }\end{array}$ & $\begin{array}{l}\text { No. of } \\
\text { leaves }\end{array}$ & $\begin{array}{c}\text { Total } \\
\text { dry } \\
\text { matter }\end{array}$ \\
\hline $\mathbf{T}_{1}$ & 78.1 & 5.15 & 29.6 & 164.5 & 72.6 & 4.16 & 26.3 & 153.5 & 87.3 & 5.43 & 30.3 & 194.5 \\
\hline $\mathbf{T}_{2}$ & 83.1 & 5.60 & 36.7 & 213.3 & 76.8 & 5.15 & 31.7 & 200.1 & 91.9 & 6.30 & 38.0 & 238.7 \\
\hline $\mathbf{T}_{3}$ & 84.8 & 5.74 & 38.0 & 227.3 & 78.0 & 5.47 & 34.3 & 212.3 & 93.9 & 6.90 & 41.5 & 249.8 \\
\hline $\mathbf{T}_{4}$ & 78.3 & 5.23 & 31.2 & 174.0 & 72.9 & 4.33 & 26.8 & 162.2 & 86.5 & 5.17 & 29.7 & 191.9 \\
\hline $\mathbf{T}_{5}$ & 84.5 & 5.70 & 37.3 & 217.6 & 77.6 & 5.35 & 34.0 & 201.4 & 90.8 & 6.24 & 37.2 & 235.7 \\
\hline $\mathbf{T}_{6}$ & 87.2 & 5.90 & 40.8 & 236.7 & 80.2 & 5.80 & 36.2 & 218.6 & 93.3 & 6.60 & 40.3 & 243.5 \\
\hline $\mathbf{T}_{7}$ & 78.2 & 5.18 & 30.6 & 171.6 & 72.8 & 4.23 & 26.4 & 158.9 & 85.7 & 5.13 & 29.5 & 188.5 \\
\hline $\mathbf{T}_{8}$ & 84.3 & 5.67 & 36.5 & 215.7 & 77.0 & 5.27 & 33.7 & 201.0 & 90.1 & 6.05 & 36.7 & 233.0 \\
\hline $\mathbf{T}_{9}$ & 85.3 & 5.82 & 38.9 & 234.6 & 78.8 & 5.60 & 36.0 & 216.4 & 92.4 & 6.41 & 38.3 & 238.2 \\
\hline $\mathbf{S . E m} \pm$ & 1.11 & 0.09 & 1.04 & 6.02 & 0.86 & 0.16 & 1.10 & 4.37 & 1.15 & 0.25 & 1.28 & 4.59 \\
\hline C.D. $(\overline{\mathbf{P}}=0.01)$ & 4.57 & 0.38 & 4.28 & 24.68 & 3.54 & 0.67 & 4.52 & 17.91 & 4.71 & 1.04 & 5.27 & 18.81 \\
\hline
\end{tabular}


Table.4 Number of fruits of tomato as influenced by graded levels of human urine, cattle urine and fertilizer in three different soils

\begin{tabular}{|c|c|c|c|c|c|c|c|c|c|}
\hline \multirow{3}{*}{ Treatments } & \multicolumn{9}{|c|}{ Number of fruits per plant } \\
\hline & \multicolumn{3}{|c|}{ Red soil } & \multicolumn{3}{|c|}{ Laterite soil } & \multicolumn{3}{|c|}{ Black soil } \\
\hline & $60 \mathrm{DAT}$ & $90 \mathrm{DAT}$ & At harvest & $60 \mathrm{DAT}$ & $90 \mathrm{DAT}$ & At harvest & $60 \mathrm{DAT}$ & $90 \mathrm{DAT}$ & At harvest \\
\hline $\mathbf{T}_{1}$ & 32.6 & 39.9 & 42.6 & 30.0 & 36.7 & 37.5 & 37.6 & 45.7 & 48.3 \\
\hline $\mathbf{T}_{2}$ & 42.8 & 48.1 & 48.8 & 39.4 & 44.3 & 44.9 & 46.4 & 52.9 & 54.5 \\
\hline $\mathbf{T}_{\mathbf{3}}$ & 44.4 & 51.2 & 52.2 & 40.8 & 47.1 & 48.0 & 50.3 & 57.5 & 57.7 \\
\hline $\mathbf{T}_{4}$ & 34.2 & 41.5 & 43.9 & 31.4 & 38.2 & 37.9 & 36.9 & 44.2 & 47.8 \\
\hline $\mathbf{T}_{5}$ & 43.3 & 48.5 & 49.8 & 40.3 & 44.9 & 47.8 & 47.2 & 52.4 & 54.0 \\
\hline $\mathbf{T}_{6}$ & 45.9 & 52.5 & 52.7 & 44.4 & 49.1 & 51.8 & 50.1 & 56.6 & 56.9 \\
\hline $\mathbf{T}_{7}$ & 33.5 & 40.2 & 43.4 & 30.8 & 37.0 & 37.7 & 35.9 & 43.9 & 46.9 \\
\hline $\mathbf{T}_{8}$ & 42.9 & 48.4 & 49.4 & 39.5 & 44.5 & 45.8 & 47.1 & 52.2 & 53.7 \\
\hline $\mathbf{T}_{9}$ & 45.5 & 52.3 & 52.5 & 43.8 & 48.0 & 49.6 & 48.8 & 56.3 & 55.3 \\
\hline S.Em \pm & 0.94 & 1.13 & 1.49 & 1.27 & 1.52 & 1.74 & 0.82 & 1.17 & 1.21 \\
\hline C.D. $(\bar{P}=0.01)$ & 3.85 & 4.63 & 6.13 & 5.21 & 6.23 & 7.15 & 3.37 & 4.80 & 4.94 \\
\hline
\end{tabular}

Where: DAT= Days after transplanting

Table.5 Yield of tomato as influenced by graded levels of human urine, cattle urine and fertilizer in three different soils

\begin{tabular}{|c|c|c|c|c|c|c|}
\hline \multirow[b]{2}{*}{ Treatments } & \multicolumn{2}{|c|}{ Red soil } & \multicolumn{2}{|c|}{ Laterite soil } & \multicolumn{2}{|c|}{ Black soil } \\
\hline & $\begin{array}{l}\text { Fresh weight (g } \\
\left.\text { fruit }^{-1}\right)\end{array}$ & Fruit yield (kg plant $_{1}^{-}$ & $\begin{array}{l}\text { Fresh weight (g } \\
\left.\text { fruit }^{-1}\right)\end{array}$ & $\begin{array}{l}\text { Fruit yield (kg } \\
\left.\text { plant }^{-1}\right)\end{array}$ & $\begin{array}{l}\text { Fresh weight (g } \\
\text { fruit }^{-1} \text { ) }\end{array}$ & $\begin{array}{l}\text { Fruit yield } \\
\left(\text { kg plant }^{-1}\right)\end{array}$ \\
\hline $\mathbf{T}_{1}$ & 50.8 & 2.2 & 50.1 & 1.97 & 60.4 & 2.24 \\
\hline $\mathbf{T}_{2}$ & 62.2 & 3.0 & 59.8 & 2.86 & 66.9 & 3.36 \\
\hline $\mathbf{T}_{3}$ & 66.3 & 3.5 & 63.8 & 3.21 & 72.2 & 3.67 \\
\hline $\mathbf{T}_{4}$ & 51.8 & 2.3 & 50.6 & 2.17 & 59.5 & 2.10 \\
\hline $\mathbf{T}_{5}$ & 63.2 & 3.1 & 62.6 & 3.14 & 68.1 & 3.30 \\
\hline $\mathbf{T}_{6}$ & 68.8 & 3.6 & 68.3 & 3.45 & 71.9 & 3.53 \\
\hline $\mathbf{T}_{7}$ & 51.0 & 2.2 & 50.3 & 2.01 & 57.9 & 2.03 \\
\hline $\mathbf{T}_{8}$ & 62.9 & 3.1 & 60.5 & 3.05 & 67.3 & 3.27 \\
\hline $\mathbf{T}_{9}$ & 68.4 & 3.6 & 65.9 & 3.32 & 71.5 & 3.45 \\
\hline $\mathbf{S . E m} \pm$ & 3.24 & 0.17 & 2.19 & 0.15 & 1.38 & 0.16 \\
\hline C.D. $(\overline{\mathbf{P}}=\mathbf{0 . 0 1})$ & 13.29 & 0.70 & 8.97 & 0.62 & 5.67 & 0.68 \\
\hline
\end{tabular}




\section{Total dry matter accumulation (g plant ${ }^{-1}$ )}

Significantly higher total dry weight plant $^{-1}$ was recorded in treatment with 2 times the recommended dose of nitrogen through human urine $\left(\mathrm{T}_{6}: 236.7 \mathrm{~g}\right.$ plant $\left.^{-1}\right)$ and it was at par with $\mathrm{T}_{9}, \mathrm{~T}_{3}, \mathrm{~T}_{5}, \mathrm{~T}_{8}$ and $\mathrm{T}_{2}$. Significantly lower total dry matter (164.5 $\mathrm{g} \mathrm{plant}^{-1}$ ) was recorded with application of recommended dose of nitrogen through chemical fertilizers $\left(T_{1}\right)$ which was on par with $\mathrm{T}_{4}$ and $\mathrm{T}_{7}$. Similar result was observed at harvest of tomato crop grown in laterite soil. Accumulation of total dry matter $\left(\mathrm{g}_{\text {plant }}{ }^{-1}\right)$ in tomato crop grown in black soil showed significant differences among the treatments at harvest.

Application of 2 times the recommended dose of nitrogen through chemical fertilizers $\left(T_{3}\right)$ recorded significantly higher total dry weight (249.8 g plant $^{-1}$ ) and it was on par with $\mathrm{T}_{6}, \mathrm{~T}_{9}$, $\mathrm{T}_{2}, \mathrm{~T}_{5}$ and $\mathrm{T}_{8}$ over recommended dose of nitrogen through chemical fertilizer $\left(\mathrm{T}_{1}: 194.5 \mathrm{~g}\right.$ plant $\left.^{-1}\right)$, human urine $\left(\mathrm{T}_{4}: 191.9 \mathrm{~g}_{\text {plant }}{ }^{-1}\right)$ and cattle urine $\left(\mathrm{T}_{7}: 188.5 \mathrm{~g}\right.$ plant $\left.^{-1}\right)$. This has been the consequence of slow and steady release and better availability of nutrients and higher nutrient uptake observed due to application of human urine in three split doses during the crop growth period in addition to the presence of all essential nutrients in human urine and cattle urine which might have stimulated the growth of vegetable crops. Hoglund (2001) and Simons and Clemens (2004) recorded similar observations on improved yield and yield attributing characters due to human urine application in rice, barley and vegetable crops like chard, turnip, carrot and fruit crops like banana, orange (Table 3 ).

\section{Yield and yield parameters of tomato}

\section{Number of fruits plant ${ }^{-1}$}

Number of fruits plant ${ }^{-1}$ recorded at 60, 90 DAT and at harvest, was significantly higher in 2 times the recommended dose of nitrogen through human urine $\left(\mathrm{T}_{6}: 45.9,52.5\right.$ and 52.7 plant-1, respectively) and it was at par with $\mathrm{T}_{9}$,
$\mathrm{T}_{3}, \mathrm{~T}_{5}, \mathrm{~T}_{8}$ and $\mathrm{T}_{2}$ but was found significantly superior over rest of the treatments $\left(\mathrm{T}_{1}, \mathrm{~T}_{4}\right.$ and $T_{7}$ ). Significantly lower number of fruits plant ${ }^{-1}$ was recorded with application of recommended dose of nitrogen through chemical fertilizers to soil $\left(\mathrm{T}_{1}\right.$ : 32.6, 39.9 and 42.6 plant $\left.^{-1}\right)$ and it was at par with $\mathrm{T}_{4}$ and $\mathrm{T}_{7}$. Similar trend was observed in laterite soil. In case of black soil, number of fruits plant $^{-1}$ varied significantly among the treatments at 60, 90 DAT and at harvest of tomato crop (Table 4). Significantly higher number of fruits plant ${ }^{-1}$ was recorded with 2 times the recommended dose of nitrogen through chemical fertilizers $\left(\mathrm{T}_{3}: 50.3,57.5\right.$ and 57.7 plant $^{-1}$, respectively) and it was on par with $\mathrm{T}_{6}, \mathrm{~T}_{9}, \mathrm{~T}_{2}, \mathrm{~T}_{5}$ and $\mathrm{T}_{8}$. Significantly lower number of fruits plant ${ }^{-1}$ was recorded with application of recommended dose of nitrogen through cattle urine to soil $\left(\mathrm{T}_{7}: 35.9,43.9\right.$ and 53.7 plant $\left.^{-1}\right)$ which was on par with $\mathrm{T}_{1}$ and $\mathrm{T}_{4}$. Hoglund (2001) and Simons and Clemens (2004) recorded similar observations on improved yield and yield attributing characters due to human urine application in rice, barley and vegetable crops like chard, turnip, carrot and fruit crops like banana, orange (Table 4).

\section{Fresh weight ( g fruit $^{-1}$ )}

Fruit weight of tomato differed significantly among the treatments. Fruit weight at harvest, was significantly higher in treatment receiving 2 times the recommended dose of nitrogen through human urine $\left(\mathrm{T}_{6}: 76.3 \mathrm{~g}\right.$ fruit $\left.^{-1}\right)$ and it was on par with $\mathrm{T}_{9}, \mathrm{~T}_{3}, \mathrm{~T}_{5}, \mathrm{~T}_{8}$ and $\mathrm{T}_{2}$. Significantly lower fruit $(58.3 \mathrm{~g})$ weight was recorded with recommended dose of nitrogen through chemical fertilizers $\left(T_{1}\right)$ which was at par with $T_{4}$ and $T_{7}$. Similar results were also observed in laterite soil also. In black soil, application of 2 times the recommended dose of nitrogen through chemical fertilizers $\left(T_{3}\right)$ showed significantly higher fruit weight $(81.5 \mathrm{~g}$ fruit $^{-1}$ ) which was at par with $\mathrm{T}_{6}, \mathrm{~T}_{9}, \mathrm{~T}_{2}, \mathrm{~T}_{5}$ and $\mathrm{T}_{8}$. Recommended dose of nitrogen through cattle urine to crop $\left(\mathrm{T}_{7}\right)$ recorded significantly lower fruit weight $\left(67.2 \mathrm{~g}_{\text {fruit }}^{-1}\right)$ and it was at par with $\mathrm{T}_{4}$ and $\mathrm{T}_{1}$ (Table 5). 


\section{Fruit weight $\left(\mathrm{kg} \mathrm{plant}^{-1}\right)$}

Application of 2 times the recommended dose of nitrogen through human urine $\left(\mathrm{T}_{6}\right)$ recorded significantly higher mean fruit weight $(3.6 \mathrm{~kg})$ plant $^{-1}$ in red soil condition and it was significantly superior over recommended dose of nitrogen through chemical fertilizers $\left(\mathrm{T}_{1}\right)$ and cattle urine $\left(\mathrm{T}_{7}\right)$ to soil $(2.2 \mathrm{~kg})$ but it was at par with $T_{9}, T_{3}, T_{5}, T_{8}$ and $T_{2}$. Similar trend was also noticed in tomato crop grown in laterite soil also. In black soil, fruit weight varied significantly due to graded levels of human, cattle urine and fertilizer. Significantly higher fruit weight was recorded in 2 times the recommended dose of nitrogen through chemical fertilizers $\left(\mathrm{T}_{3}: 3.67 \mathrm{~kg}\right)$, which was significantly superior over $\mathrm{T}_{1}, \mathrm{~T}_{4}$ and $\mathrm{T}_{7}$ but was on par with rest of the treatments (Table 5). In black soil, higher yield was recorded with application of 2 times the recommended dose of $\mathrm{N}$ through chemical fertilizer but was on par with application of human urine and cattle urine which might be due to higher $\mathrm{pH}$ of soil leading to loss of applied nitrogen through volatilization. Olga Singurindy et al., (2006) observed ammonia volatilization during the first day of the treatments, with volatilization rate closely related to evaporation rates in both sand textures (fine and coarse). Sand texture caused reductions in the urine evaporation rate and therefore in $\mathrm{NH}_{3}$ volatilization rates. Urine evaporation increased air-filled pore space, thereby improving aeration conditions in the sand that contribute to nitrification and dominance of $\mathrm{N}_{2} \mathrm{O}$ production. Moreover, evaporation of urine, enriched with dissolved $\mathrm{N}_{2} \mathrm{O}$, increased total $\mathrm{N}_{2} \mathrm{O}$ emission.

\section{References}

Guadarrama, R.O., Pichardo, N.A., and Morales Oliver, E. 2001. Urine and compost efficiency applied to lettuce under greenhouse conditions in Temixco, Morales, Mexico. In: Abstract Volume, First International Conference on Ecological Sanitation 5-8 November, Nanning, China.

Hoglund, C., 2001. Evaluation of microbial health risks associated with the reuse of source separated human urine, Ph. D. Thesis, Royal Inst. of Technology, Department of Biotechnology.

Jonsson, H. 1997. Assessment of sanitation systems and reuse of urine. Ecological alternatives in sanitation. Water Res., No.-9: p11-22.

Kedar Man Prajapati, and Deepak Raj Gajurel,. 2003. Nutrient uptake by different vegetable plants from source separated human urine. $2^{\text {nd }}$ Inter. Symp. Eco. Sanit., p-55.

Olga Singurindy, Brian, K., Richards, Marina Molodovskaya, and Tammo S. Steenhuis,. 2006. Nitrous oxide and ammonia emissions from urine-treated soils: texture effect. Vadose Zone J., 5:1236-1245.

Peter Morgan, R. 2004. Ecological Sanitation in Zimbabwe. A compilation of manuals and experiences. 4:100-105. Aquamor Pvt. Ltd. Harare.

Simons J, Clemens, J. 2004. 'The use of separated human urine as mineral fertilizer'. In: Ecosan - Closing the loop. Proc. $2^{\text {nd }}$ Intl. Symp. Ecol. Sani., incorporating the $1^{\text {st }}$ IWA specialist group conference on sustainable sanitation, $7^{\text {th }}$ $11^{\text {th }}$ April, Lübeck, Germany. pp 595-600.

Sridevi, G., Srinivasamurthy, C.A., and Bhaskar, S., Viswanath, S. 2009. Evaluation of source separated human urine (ALW) as a source of nutrients for banana cultivation and impact on quality parameter. ARPN J. Agril. Bio. Sci., 40(5): 44-48.

\section{How to cite this article:}

Yogeeshappa, H. and Srinivasamurthy, C.A. 2017. Effect of Human Urine and Cattle Urine on Growth and Yield of Tomato (Solanum lycopersicum) in Red, Laterite and Black Soils of Karnataka, India. Int.J.Curr.Microbiol.App.Sci. 6(12): 1597-1605. doi: https://doi.org/10.20546/ijcmas.2017.612.179 